\title{
Correction to: Aversion to Happiness Across Cultures: A Review of Where and Why People are Averse to Happiness
}

\author{
Mohsen Joshanloo ${ }^{1} \cdot$ Dan Weijers $^{2}$
}

Published online: 25 March 2021

(c) The Author(s) 2021

\section{Correction to: J Happiness Stud (2014) 15:717-735 https://doi.org/10.1007/s10902-013-9489-9}

The article "Aversion to Happiness Across Cultures: A Review of Where and Why People are Averse to Happiness", written by Mohsen Joshanloo and Dan Weijers, was originally published Online First without Open Access. After publication in volume 15, issue 3, page 717-735 the author decided to opt for Open Choice and to make the article an Open Access publication. Therefore, the copyright of the article has been changed to The Author(s) 2021 and the article is forthwith distributed under the terms of the Creative Commons Attribution 4.0 International License, which permits use, sharing, adaptation, distribution and reproduction in any medium or format, as long as you give appropriate credit to the original author(s) and the source, provide a link to the Creative Commons licence, and indicate if changes were made. The images or other third party material in this article are included in the article's Creative Commons licence, unless indicated otherwise in a credit line to the material. If material is not included in the article's Creative Commons licence and your intended use is not permitted by statutory regulation or exceeds the permitted use, you will need to obtain permission directly from the copyright holder. To view a copy of this licence, visit http://creativecommons.org/licenses/by/4.0.

The original article has been corrected.

Publisher's Note Springer Nature remains neutral with regard to jurisdictional claims in published maps and institutional affiliations.

The original article can be found online at https://doi.org/10.1007/s10902-013-9489-9.

Mohsen Joshanloo

mjoshanloo@hotmail.com

Dan Weijers

Dan.Weijers@vuw.ac.nz

1 School of Psychology, Victoria University of Wellington, Wellington, New Zealand

2 Philosophy Programme, Victoria University of Wellington, Wellington, New Zealand 